\title{
Aktivitas Antibakteri Ekstrak Metanol Kulit Buah Kawista (Limonia acidissima) terhadap Shigella dysenteriae dan Salmonella typhi
}

\author{
Veryanti, P.R ${ }^{1}$, Kusuma I.M ${ }^{1}$ dan Ramadhina, $E^{1}$ \\ ${ }^{1}$ Program Studi Farmasi, Fakultas Farmasi, Institut Sains dan Teknologi Nasional, Jalan Moh. Kahfi II, Srengseng Sawah, Jagakarsa, \\ Jakarta Selatan, DKI Jakarta, Indonesia 12630
}

Reception date of the manuscript: 28 November 2020

Acceptance date of the manuscript: 4 Desember 2021

Publication date: 31 Desember 2021

\begin{abstract}
Shigella dysenteriae and Salmonella typhi are known as gastrointestinal infections-causing bacteria. Kawista plants are widely grown in Indonesia, used as an alternative therapy for treating diarrhea. The chemical compounds of kawista peel presumed to have antibacterial activity. The aim of this study was to determine the antibacterial activity of kawista peel extract against Shigella dysenteriae and Salmonella typhi. The study began with the extraction of kawista peel through the maceration method, using methanol as a solvent. Furthermore, phytochemical screening and antibacterial activity test was carried out. The test for the antibacterial activity of kawista peel extract used the disc diffusion method. Various extract concentrations were used in this study, there were 5\%, 10\%, 20\%, 40\% and $80 \%$. The antibacterial activity test was measured based on the inhibition zone diameter. The results showed that the higher concentration of kawista peel extract, the stronger antibacterial activity was. At $5 \%$ concentration, the mean of inhibition zone diameter for Shigella dysenteriae and Salmonella typhi were $7.91 \mathrm{~mm}$ and $7.73 \mathrm{~mm}$, respectively. Meanwhile, at a concentration of $80 \%$, the extract had the strongest antibacterial activity (inhibition zone diameter $21.42 \mathrm{~mm}$ in Shigella dysenteriae; $20.93 \mathrm{~mm}$ in Salmonella typhi). Kawista peel extract (Limonia acidissima) had antibacterial activity against Shigella dysenteriae and Salmonella typhi.
\end{abstract}

Keywords-Antibacterial, Kawista, Limonia acidissima, Salmonella typhi, Shigella dysenteriae.

Abstrak - Shigella dysenteriae dan Salmonella typhi merupakan bakteri yang dapat menyebabkan infeksi pada saluran cerna. Kawista banyak ditemui di Indonesia dan dapat dijadikan terapi alternatif untuk mengatasi diare. Kandungan kimia yang terdapat pada kulit buah kawista diduga dapat berkhasiat sebagai antibakteri. Tujuan dari penelitian ini adalah untuk mengetahui aktivitas antibakteri ekstrak kulit buah kawista (Limonia acidissima) terhadap bakteri Shigella dysenteriae dan Salmonella typhi. Tahap penelitian diawali dengan proses ekstrasi kulit buah kawista melalui metode maserasi, menggunakan pelarut metanol. Selanjutnya, dilakukan penapisan fitokimia dan pengujian aktivitas antibakteri. Pengujian aktivitas antibakteri ekstrak kulit buah kawista menggunakan metode difusi cakram dalam berbagai konsentrasi, yaitu 5\%,10\%, 20\%, 40\% dan 80\% ekstrak. Uji aktivitas antibakteri diukur berdasarkan diameter daerah hambat (DDH) yang dihasilkan. Hasil penelitian menunjukkan bahwa semakin tinggi konsentrasi ekstrak kulit buah kawista, semakin kuat aktivitas antibakteri yang diberikan. Pada konsentrasi 5\%, rata-rata DDH untuk bakteri Shigella dysenteriae dan Salmonella typhi masing-masing adalah 7,91 $\mathrm{mm}$ dan $7,73 \mathrm{~mm}$. Pada konsentrasi $80 \%$, ekstrak memiliki aktivitas antibakteri yang paling kuat dengan rata-rata DDH 21,42 mm pada Shigella dysenteriae dan 20,93 mm pada Salmonella typhi. Ekstrak kulit buah kawista (Limonia acidissima) memiliki aktivitas antibakteri terhadap Shigella dysenteriae dan Salmonella typhi.

Kata Kunci-Antibakteri, Kawista, Limonia acidissima, Salmonella typhi, Shigella dysenteriae.

\section{Pendahuluan}

Shigella dysenteriae dan Salmonella typhimerupakan bakteri pathogen penyebab diare pada manusia (Dekker Frank, 2015). Berdasarkan profil kesehatan Indonesia, terjadi $10 \mathrm{ka}-$ li kejadian luar biasa (KLB) diare yang tersebar di 8 provinsi di Indonesia dengan jumlah penderita sebanyak 756 orang

Penulis koresponden: Rika Veryanti, E-mail: puturika eryanti@istn.ac.id dan 36 kematian (Case Fatality Rate 4,76\%). Angka kematian (CFR) pada KLB diare tahun 2018 ini masih cukup tinggi karena CFR yang diharapkan pada KLB adalah $<1 \%$ (Kemenkes RI, 2019). Salah satu upaya masyarakat dalam mengatasi diare adalah melalui swamedikasi. Namun sayangnya perilaku swamedikasi di masyarakat tidak diimbangi dengan pengetahuan yang cukup. Sebuah penelitian menunjukkan bahwa sebanyak $66 \%$ dari responden yang pernah melakukan swamedikasi, menggunakan antibiotik yang tidak tepat indikasi, termasuk untuk mengobati diare (Nisak, 2016). 
Penggunaan antibiotik yang tidak tepat ini dapat menyebabkan resistensi bakteri terhadap antibiotik. Beberapa penelitian melaporkan kejadian resistensi bakteri penyebab diare terhadap antibiotik seperti asam nalidiksat, eritromisin, tetrasiklin, kloramfenikol, amoksisilin dan ampisilin (Novard, Suharti, Rasyid, 2019; Sumampouw, 2018).

Permasalahan yang ditimbulkan dari penggunaan antibiotik seperti uraian di atas, menyebabkan masyarakat memilih untuk kembali ke pengobatan tradisional. Pengobatan tradisional dinilai lebih aman karena memiliki efek samping yang relatif lebih rendah dibandingkan pengobatan modern (Sumayyah Salsabila, 2017). Keanekaragaman hayati yang dimiliki Indonesia serta diikuti dengan meningkatnya minat masyarakat untuk kembali ke alam menyebabkan pengembangan bahan baku obat tradisional di Indonesia menjadi meningkat. Salah satu tanaman yang berpotensi untuk dikembangkan adalah kawista (Limonia acidissima). Kawista merupakan buah asli India yang banyak tumbuh di berbagai daerah di Indonesia (Gunarti, 2017). Buah ini dipercaya masyarakat memiliki berbagai manfaat bagi kesehatan, salah satunya adalah sebagai antidiare. Hal ini disebabkan oleh potensi aktivitas antibakteri yang dimilikinya (Rini, Supriatno, Rahmatan, 2017). Identifikasi dan isolasi senyawa aktif dari ekstrak tanaman kawista seperti buah, daun dan kulit batang telah banyak dilakukan dan terbukti memiliki aktivitas sebagai antioksidan, antihiperurisemia, hepatoprotektor dan sebagai antibakteri (Gunarti, 2017; Nugraheni, Ikasari, Kusmita, 2016; Ridwanuloh Mursal, 2018; Rustiah Umriani, 2018; Supriatno Rini, 2018).

Salah satu bagian dari kawista yang masih belum banyak dipelajari adalah kulit buahnya. Kulit buah kawista merupakan limbah dari buah kawista yang dianggap tidak memiliki manfaat bagi kesehatan, padahal di sisi lain sebuah penelitian menunjukkan bahwa ekstrak kulit buah kawista juga mengandung metabolit sekunder seperti alkaloid, flavonoid, saponin, tannin dan terpenoid (Kusuma, Veryanti, Saragih, 2019). Metabolit sekunder tersebut diduga memiliki aktivitas antibakteri terhadap kuman penyebab diare. Berdasarkan uraian di atas maka dilakukan uji aktivitas antibakteri ekstrak kulit buah kawista (Limonia acidissima) terhadap Shigella dysenteriae dan Salmonella typhi.

\section{BAHAN DAN METODE}

\section{Bahan dan Alat}

Bahan-bahan yang digunakan dalam penelitian ini adalah kulit buah kawista (Limonia acidissima L.), Shigella dysenteriae dan Salmonella typhi, Metanol (Herbalux®), Amoniak 25\% (Merck), Kloroform (Merck), HCl 2N (Merck), Pereaksi Bouchardat (Nitrakimia), Pereaksi Mayer (Nitrakimia), Pereaksi Dragendorf (Nitrikimia), Alumunium klorida $10 \%$ (Merck), Larutan natrium nitrit 5\% (Merck), Natrium hidroksida $1 \mathrm{~N}$ (Merck), $\mathrm{H}_{2} \mathrm{SO}_{4}$ pekat (Merck), Feri (III) klorida (Merck), Eter (Merck), Asetat anhidrat (Merck) dan Aquadest (Herbalux®), Cakram ciprofloxacin (Oxoid), Cakram Kosong (Oxoid), Media Mueller Hinton Agar (Oxoid), Pewarnaan Gram A, B, D dan minyak imersi, Larutan $\mathrm{NaCl}$ (Otsu) dan Alkohol (Herbalux $\left.{ }^{\circledR}\right)$.

Alat yang digunakan adalah oven, vacuum rotary evaporator, Erlenmeyer (Pyrex), timbangan digital, blender (Philips), hot plate, spatula, batang pengaduk, gelas ukur (Pyrex), pinset, alumunium foil, kertas saring, pipet tetes, botol vial, cawan petri, objek glass, cover glass, inkubator, lemari pendingin, laminar, air flow, autoklaf, ose, Bunsen, mikropipet, tabung reaksi (Pyrex), rak tabung reaksi, corong, vortex, penangas, gunting, lampu spirtus dan jangka sorong (Veanier).

\section{Metode}

Sampel buah kawista yang digunakan dalam penelitian diperoleh dari Jawa Barat. Selanjutnya dilakukan determinasi di Herbarium Bogoriense, Badan Penelitian dan Pengembangan Botani, Pusat Penelitian dan Pengembangan Biologi, Lembaga Ilmu Pengetahuan Indonesia (LIPI), Bogor. Setelah penetapan kebenaran sampel, kemudian dilakukan pembuatan ekstrak kulit buah kawista, penapisan fitokimia dan pengujian aktivitas antibakteri di Laboratorium Mikrobiologi dan Laboratorium Fitokimia, Institut Sains dan Teknologi Nasional Jakarta.

\section{Pembuatan Ekstrak}

Pembuatan ekstrak kulit buah kawista diawali dengan sortasi basah. Sebanyak 1,44 Kg kulit buah kawista dicuci, dipotong kecil dan diangin-anginkan hingga kering. Selanjutnya dilakukan sortasi kering dengan cara memisahkan bagian yang tidak diinginkan seperti sisa daging buah atau kotoran lainnya, hingga diperoleh simplisia kering. Simplia kering dihaluskan dengan blender dan diperoleh serbuk simplisia kulit buah kawista. Serbuk kering tersebut disimpan dalam wadah tertutup dan terlindung dari cahaya. Lima ratus gram serbuk kulit buah kawista di maserasi dalam $5 \mathrm{~L}$ pelarut metanol selama 24 jam. Sesekali di aduk, selanjutnya filtrat disaring dan diremaserasi sebanyak 2 kali. Ekstrak yang diperoleh dipekatkan dengan rotary evaporator dan waterbath, hingga menjadi ekstrak kental kulit buah kawista.

\section{Penampisan Fitokimia}

Penapisan fitokimia bertujuan untuk mendeteksi kandungan metabolit sekunder yang terdapat pada ekstrak kulit buah kawista seperti : Alkaloid, Flavonoid, Saponin, Tanin, dan Triterpenoid. Adapun langkah-langkah yang dilakukan adalah sebagai berikut: (Gunarti, 2017)

\section{Alkaloid}

Sebanyak $1 \mathrm{~g}$ ekstrak diteteskan $5 \mathrm{ml}$ amoniak $\left(\mathrm{NH}_{2}\right) 25 \%$ dalam gelas beker lalu ditambahkan $20 \mathrm{ml}$ kloroform dan dipanaskan di atas penangas air. Selanjutnya disaring dan filtrat yang diperoleh diuapkan hingga setengahnya. Sisa penguapan ditampung pada tabung reaksi. Sebanyak $1 \mathrm{ml}$ asam klorida $(\mathrm{HCl}) 2 \mathrm{~N}$ ditambahkan pada tabung reaksi, kemudian dikocok dan dibiarkan hingga terbentuk 2 lapisan. Lapisan jenuh yang terbentuk dimasukkan ke dalam 3 tabung reaksi dengan jumlah yang sama. Kemudian ditambahkan pereaksi Mayer pada tabung 1, pereaksi Bouchardat pada tabung 2, dan pereaksi Dragendorft pada tabung ke 3. Hasil positif mengandung alkaloid ditandai dengan terbentuknya endapan putih pada tabung 1, endapan coklat pada tabung 2 dan endapan merah bata pada tabung ke-3.

\section{Flavonoid}

Satu gram ekstrak kulit buah kawista ditambahkan 100 $\mathrm{ml}$ air panas, kemudian disaring. Sebanyak $5 \mathrm{ml}$ filtrat dimasukkan kedalam tabung reaksi, ditambahkan $1 \mathrm{ml}$ larutan natrium nitrit $\left(\mathrm{NaNO}_{2}\right) 5 \%$ dan $1 \mathrm{ml}$ alumunium klorida $\left(\mathrm{AlCl}_{2}\right) 10 \%$ lalu dikocok. Selanjutnya ditambahkan $2 \mathrm{ml}$ $\mathrm{NaOH} 1 \mathrm{~N}$. Jika larutan berubah menjadi merah atau jingga 
maka ekstrak positif mengandung flavonoid.

\section{Saponin}

Sebanyak $1 \mathrm{~g}$ esktrak diekstraksi dengan air panas $100 \mathrm{ml}$ kemudian disaring. Filtrat sebanyak $10 \mathrm{ml}$ dimasukkan ke dalam tabung reaksi, kemudian dikocok kuat selama 10 detik. Jika terbentuk busa stabil setinggi 1 sampai $10 \mathrm{~cm}$ selama 10 menit dan tidak hilang dengan penambahan 1 tetes $\mathrm{HCl} 2 \mathrm{~N}$, maka ekstrak mengandung saponin.

\section{Tanin}

Satu gram ekstrak kulit buah kawista diekstraksi dengan $100 \mathrm{ml}$ air panas, kemudian disaring. Sebanyak $5 \mathrm{ml}$ filtart dimasukkan kedalam tabung reaksi kemudian ditambahkan larutan ferri klorida $\left(\mathrm{FeCl}_{3}\right)$. Jika terbentuknya warna hijau, ungu atau hitam maka larutan tersebut mengandung tanin.

\section{Terpenoid}

Sebanyak 1 g ekstrak dimaserasi dengan $20 \mathrm{ml}$ eter selama 2 jam kemudian disaring dan diuapkan dalam cawam penguap hingga diperoleh residu, lalu ditambahkan 2 tetes asam asetat anhidrat dan $2 \mathrm{ml}$ kloroform, kemudian dipindahkan kedalam tabung reaksi. Perlahan-lahan ditambahkan $1 \mathrm{ml} \mathrm{H}_{2} \mathrm{SO}_{4}$ pekat (pereaksi Liebermann-Burchard) melalui dinding tabung. Apabila terbentuk warna ungu menunjukkan adanya kandungan terpenoid.

\section{Pengujian Aktivitas Antibakteri}

Pengujian aktivitas antibakteri dari ekstrak kulit buah kawista dilakukan secara in-vitro dengan metode difusi cakram kertas. Konsentrasi ekstrak yang diujikan bervariasi, yaitu dari 5\%,10\%, 20\%, 40\% hingga $80 \%$. Sebagai kontrol positif digunakan antibiotik siprofloksasin dan aquadest sebagai kontrol negatif. Suspensi bakteri Shigella dysenteriae dan Salmonella typhi disebar ke permukaan media MHA, kemudian cakram yang mengandung larutan uji, kontrol positif dan kontrol negatif diletakkan pada permukaan media secara steril. Media diinkubasi dalam inkubator pada suhu $37^{\circ} \mathrm{C}$ selama 24 jam. Selanjutnya diameter daerah hambat (DDH) yang terbentuk diukur dengan menggunakan jangka sorong. Pengulangan dilakukan sebanyak 3 kali.

\section{Analisis Data}

Analisis data dilakukan pada hasil uji aktivitas antibakteri ekstrak metanol kulit buah kawista terhadap Shigella dysenteriae dan Salmonella typhi. Data diperoleh dari pengukuran DDH yang diberikan pada masing-masing cakram kertas yang mengandung sampel uji dan kontrol. Dilakukan perhitungan terhadap nilai rata-rata dan standar deviasi dari DDH yang dihasilkan, kemudian dilakukan uji komparatif aktivitas antibakteri pada kedua kelompok bakteri melalui uji-t ( $t$ test). Aktivitas antibakteri ekstrak metanol kulit buah kawista terhadap Shigella dysenteriae dan Salmonella typhi dikatakan berbeda secara signifikan apabila nilai p-value $<0,05$.

\section{HASIL}

Uji penapisan fitokimia terhadap ekstrak kulit buah kawista (Limonia acidissima) menunjukkan bahwa ekstrak mengandung alkaloid, flavonoid, saponin, tanin dan terpenoid. Hasil ini ditampilkan pada Tabel 1.

Aktivitas antibakteri dari kandungan metabolit sekunder ekstrak kulit buah kawista terhadap Shigella dysenteriae dan Salmonella typhi pada penelitian ini, diuji melalui penguku-
Tabel 1: Hasil Penapisan Fitokimia Ekstrak Metanol KULIT BUAh KaWista)

\begin{tabular}{llc}
\hline Identifikasi & Hasil Pengamatan & Ekstrak Metanol \\
\hline Alkaloid & Endapan coklat, & + \\
putih dan merah bata & + \\
Flavonoid & Warna jingga & + \\
Saponin & Busa stabil 1cm & + \\
Tanin & Warna hijau & + \\
Terpenoid & Cincin ungu & + \\
\hline
\end{tabular}

ran diameter daerah hambat (DDH) yang dihasilkan pada cakram kertas. Gambar 1 dan 2 menunjukkan adanya perbedaan DDH pada masing-masing cakram dalam berbagai konsentrasi, baik pada media dengan Shigella dysenteriae maupun Salmonella typhi.

Perbandingan hasil pengukuran DDH pada media dengan Shigella dysenteriae dan Salmonella typhi ditunjukkan pada tabel 2. Berdasarkan tabel diatas diketahui bahwa ekstrak metanol kulit buah kawista memiliki aktivitas antibakteri baik terhadap Shigella dysenteriae maupun Salmonella typhi.

\section{Pembahasan}

Tabel 1 menunjukkan kandungan metabolit sekunder yang terdapat pada ekstrak kulit buah kawista. Kandungan metabolit sekunder yang terdapat pada ekstrak kulit buah kawista juga ditemukan pada ekstrak bagian lainnya seperti: daging buah, daun dan kulit batang kawista (Gunarti, 2017; Nugraheni dkk., 2016; Ridwanuloh Mursal, 2018; Supriatno Rini, 2018). Metabolit sekunder ini berpotensi untuk dimanfaatkan sebagai terapi alternatif berbasis bahan alam untuk mengatasi masalah kesehatan pada masyarakat. Hasil penelitian sebelumnya juga menunjukkan bahwa ekstrak kulit buah kawista berpotensi memiliki manfaat bagi kesehatan, yaitu sebagai antihiperuresemia. Pada penelitian tersebut dibuktikan bahwa terjadi penurununan kadar asam urat darah pada mencit jantan yang mengalami hiperuresemia akibat diinduksi dengan hati ayam segar (Kusuma dkk., 2019). Penelitian lainnya menyebutkan bahwa ekstrak buah kawista memiliki aktivitas antibakteri terhadap E. Coli (Supriatno Rini, 2018). Disamping itu, ekstrak etanol daun kawista juga dapat dikembangkan menjadi sediaan topical krim yang diaplikasikan pada kulit karena aktivitas antibakteri dari metabolit sekundernya terhadap Staphylococcus aureus (Nugraheni dkk., 2016).

Dalam uji aktivitas antibakteri, digunakan kontrol positif dan negatif. Kontrol positif yang digunakan dalam penelitian ini adalah siprofloksasin. Siprofloksasin memberikan DDH yang paling besar dibandingkan dengan cakram lainnya. Siprofloksasin merupakan antibiotik spektrum luas yang telah terbukti efektif dalam membunuh bakteri gram positif maupun negatif. Antibiotik ini bekerja dengan menghambat replikasi DNA dan memberikan efek sitotoksik pada sel bakteri (Raini, 2017). Hal sebaliknya terjadi pada kontrol negatif (aquadest), dimana tidak ada zona hambat yang dihasilkan oleh cakram karena aquadest tidak memiliki aktivitas antibakteri.

Tabel 2 menunjukkan bahwa semakin tinggi konsentrasi ekstrak pada cakram, semakin besar daya hambat yang dihasilkan. Menurut Davis dan Stout (1971), aktivitas antibakteri 


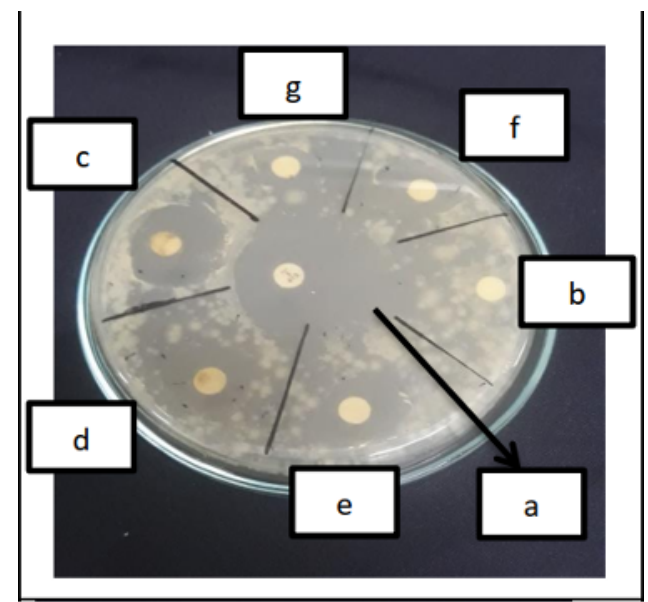

Gambar. 1: Uji Aktivitas Antibakteri Ekstrak Metanol Kulit Buah Kawista terhadap Shigella dysenteriae Keterangan: $a=$ siprofloksasin; $b=$ aquadest; $c=80 \% ; d=40 \% ; e=20 \% \mathrm{f}=10 \% ; \mathrm{g}=5 \%$

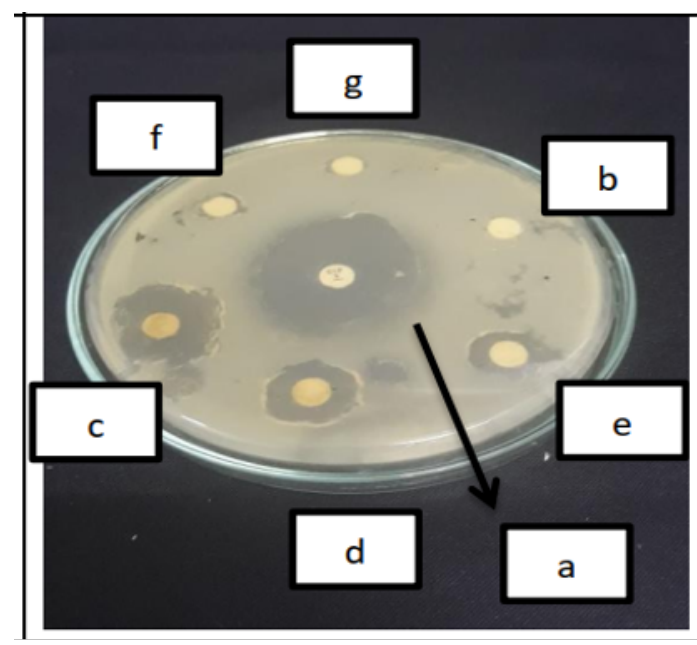

Gambar. 2: Uji Aktivitas Antibakteri Ekstrak Metanol Kulit Buah Kawista terhadap Salmonella typhi Keterangan: $a=$ siprofloksasin; $b=$ aquadest; $c=80 \% ; d=40 \% ; e=20 \% \mathrm{f}=10 \% ; \mathrm{g}=5 \%$

Tabel 2: Hasil Pengujian Aktivitas Antibakteri)

\begin{tabular}{lcll}
\hline Sampel Uji & $\begin{array}{c}\text { Rata-rata DDH pada } \\
\text { Shigella dysenteriae }(\mathrm{mm})\end{array}$ & $\begin{array}{l}\text { Rata-rata DDH pada } \\
\text { Salmonella typhi }(\mathrm{mm})\end{array}$ & P-value \\
\hline EMK 5\% & $7,91 \pm 0,85$ & $7,73 \pm 0,55$ & $0,38^{*}$ \\
EMK 10\% & $11,19 \pm 1,43$ & $11,30 \pm 1,02$ & $0,46^{*}$ \\
EMK 20\% & $14,68 \pm 1,17$ & $13,53 \pm 2,36$ & $0,25^{*}$ \\
EMK 40\% & $17,25 \pm 1,46$ & $15,51 \pm 1,76$ & $0,13^{*}$ \\
EMK 80\% & $21,42 \pm 2,25$ & $20,93 \pm 1,20$ & $0,38^{*}$ \\
Kontrol + & $33,56 \pm 0,72$ & $31,13 \pm 1,54$ & $0,07^{*}$ \\
Kontrol - & $0 \pm 0$ & $0 \pm 0$ & - \\
\hline
\end{tabular}

Keterangan: EMK= Ekstrak Metanol Kulit Buah Kawista; Kontrol + = Siprofloksasin; Kontrol - = Aquadest; * = uji-t (t-test) antar kedua kelompok bakteri ( $\mathrm{P}>0,05$; tidak bermakna)

dibagi menjadi 4 kategori, yaitu kategori lemah bila DDH yang diberikan $5 \mathrm{~mm}$, kategori sedang dengan DDH antara 5-10 mm, kategori kuat ditunjukkan oleh DDH antara 10$20 \mathrm{~mm}$ dan kategori sangat kuat bila DDH >20 mm. Berdasarkan kategori tersebut, maka hasil penelitian menunjukkan bahwa ekstrak kulit buah kawista pada konsentrasi 5\% memiliki aktivitas antibakteri dengan kategori sedang. Sedangkan pada konsentrasi 10\%, 20\% dan 40\%, ekstrak kulit buah kawista memiliki aktivitas antibakteri yang kuat. Aktivitas antibakteri yang paling tinggi (kategori sangat kuat) ditunjukkan oleh ekstrak dengan konsentrasi $80 \%$.

Melalui uji t-test, tabel 2 juga menunjukkan aktivitas antibakteri yang dihasilkan oleh ekstrak kulit buah kawista pada kedua kelompok bakteri (Shigella dysenteriae dan Salmonella typhi) tidak terdapat perbedaan yang signifikan ( $\mathrm{p}$-value $>0,05$ ). Dengan kata lain aktivitas antibakteri ekstrak kulit buah kawista terhadap Shigella dysenteriae sama dengan aktivitasnya terhadap Salmonella typhi. Hal ini bisa disebabkan 
karena kedua bakteri tersebut sama-sama merupakan bakteri gram negatif dan termasuk keluarga Enterobacteriaceae (Dekker Frank, 2015).

Aktivitas antibakteri ekstrak kulit buah kawista terhadap Shigella dysenteriae dan Salmonella typhiini diperoleh dari kemampuan alkaloid dalam menghambat pembentukan peptidoglikan pada dinding sel bakteri dan peningkatan permeabilitas membrane oleh saponin sehingga menyebabkan kebocoran protein dan enzim pada sel bakteri (Rahman, Haniastuti, Utami, 2017). Disamping itu, potensi antibakteri juga ditunjukkan oleh metabolit sekunder lainnya seperti tannin yang mampu mendenaturasi protein bakteri, flavonoid menghambat sintesis asam nukleat serta metabolit terpenoid yang dapat merusak membran luar dinding sel bakteri. Kombinasi mekanisme kerja dari metabolit sekunder yang terkandung dalam ekstrak kulit buah kawista (Limonia acidissima) dapat menghambat pertumbuhan bakteri Shigella dysenteriae dan Salmonella typhi(Saifudin, 2014).

\section{KESIMPULAN}

Ekstrak kulit buah kawista (Limonia acidissima) memiliki aktivitas antibakteri terhadap Shigella dysenteriae dan Salmonella typhi. Kandungan metabolit sekunder dari ekstrak kulit buah kawista yang terdiri dari alkaloid, saponin, tannin, flavonoid dan terpenoid dapat menghambat pertumbuhan bakteri melalui berbagai mekanisme. Metabolit sekunder tresebut menghambat pertumbuhan bakteri dengan cara merusak dinding sel bakteri, meningkatkan permeabilitas membran, mendenaturasi protein serta menghambat sintesis asam nukleat sel bakteri.

\section{UCAPAN TERIMA KASIH}

Ucapan terimakasih disampaikan kepada Lembaga Ilmu Pengetahuan Indonesia (LIPI) dan LPPM Institut Sains dan Teknologi Nasional atas dukungan yang diberikan terhadap penelitian dan penulisan karya tulis ilmiah ini.

\section{Daftar Pustaka}

Davis, W. W., Stout, T. R. (1971). Disc Plate Method of Microbiological Antibiotic Assay. Applied Microbiology, 22(4), 666-670.

Dekker, J. P., Frank, K. M. (2015). Salmonella, Shigella, and Yersinia. Clinics in Laboratory Medicine, 35(2), 225-246. https://doi.org/10.1016/j.cll.2015.02.002

Gunarti, N. S. (2017). Uji Pendahuluan dan Karakterisasi Buah Kawista (Limonia accidisima) Khas Karawang. PharmaXplore, 2(2), 136-144.

Kemenkes RI. (2019). Profil Kesehatan Indonesia 2018. Jakarta: Kementerian Kesehatan Republik Indonesia.

Kusuma, I. M., Veryanti, P. R., Saragih, E. T. D. (2019). Pemanfaatan Ekstrak Kulit Buah Kawista (Limonia acidissima) sebagai Anti Asam Urat secara In Vivo pada Mencit Jantan. Saintech Farma, 12(2), 65-69.

Nisak, M. (2016). Profil Penggunaan dan Pengetahuan Antibiotik pada Ibu-ibu. Jurnal Farmasi Komunitas, 3(1), 12-17.

Novard, M. F. A., Suharti, N., Rasyid, R. (2019). Gambaran Bakteri Penyebab Infeksi Pada Anak Berdasarkan Jenis Spesimen dan Pola Resistensinya di Laboratorium RSUP Dr. M. Djamil Padang Tahun 2014-2016. Jurnal Kesehatan Andalas, 8(2S), 26-32. https://doi.org/10.25077/jka.v8i2S.955
Nugraheni, C. K., Ikasari, E. D., Kusmita, L. (2016). Optimasi Basis Krim Ekstrak Etanol Daun Kawista (Limonia acidissima L.) sebagai Antibakteri Staphylococcus aureus. Media Farmasi Indonesia, 11(1), 993-1003.

Rahman, F. A., Haniastuti, T., Utami, T. W. (2017). Skrining fitokimia dan aktivitas antibakteri ekstrak etanol daun sirsak (Annona muricata L.) pada Streptococcus mutans ATCC 35668. Majalah Kedokteran Gigi Indonesia, 3(1), 1-7. https://doi.org/10.22146/majkedgiind.11325

Raini, M. (2017). Antibiotik Golongan Fluorokuinolon: Manfaat dan Kerugian. Media Penelitian dan Pengembangan Kesehatan, 26(3), 163-174. https://doi.org/10.22435/mpk.v26i3.4449.163-174

Ridwanuloh, D., Mursal, I. L. P. (2018). Isolasi Metabolit Sekunder dari Daun Kawista (Limonia acidissima L.). PharmaXplore, 3(1), 159-163.

Rini, A. A., Supriatno, Rahmatan, H. (2017). Skrining Fitokimia dan Uji Antibakteri Ekstrak Etanol Buah Kawista (Limonia acidissima L.) dari Daerah Kabupaten Aceh Besar terhadap Bakteri Escherichia coli. Jurnal Ilmiah Mahasiswa Fakultas Keguruan dan Ilmu Pendidikan Unsyiah, 2(1), 12.

Rustiah, W., Umriani, N. (2018). Uji Aktivitas Antioksidan Pada Ekstrak Buah Kawista (Limonia acidissima) Menggunakan Spektrofotometer UV-Vis. Indonesian Journal of Chemical Research, 6(1), 22-25. https://doi.org/10.30598//ijcr.2018.6-wao

Saifudin, A. (2014). Senyawa Alam Metabolit Sekunder: Teori, Konsep, dan Teknik Pemurnian (1st ed.). Yogyakarta.

Sumampouw, O. J. (2018). Uji Sensitivitas Antibiotik terhadap Bakteri Escherichia coli Penyebab Diare Balita di Kota Manado. Journal of Current Pharmaceutical Sciences, 2(1), 104-110.

Sumayyah, S., Salsabila, N. (2017). Obat Tradisional: Antara Khasiat dan Efek Sampingnya. Majalah Farmasetika, 2(5), 1-4. https://doi.org/10.24198/farmasetika.v2i5.16780

Supriatno, Rini, A. A. (2018). Uji Fitokimia dan Antibakteri Ekstrak Etanol Buah Kawista (Limonia acidissima L.) pada Bakteri Escherichia coli. Prosiding Seminar Nasional Pendidikan Biologi, 236-241 